\title{
Upaya Hakim dalam Menekan Tingkat Perceraian Akibat Perselisihan dan Pertengkaran pada Masa Pandemi COVID-19 di Pengadilan Agama Bandung
}

Mujaadilah*

Prodi Hukum Keluarga Islam, Fakultas Syariah, Universitas Islam Bandung, Indonesia.

*muja0adilah@gmail.com

\begin{abstract}
The COVID-19 pandemic caused the most impact of domestic life: an economy or a nafkah to which a husband and wife repeatedly quarreled and argued until reconciliation could not be tolerated and then submit divorce to the Bandung court of religion. Divorce cause by repeatedly quarreled and argued become highest reason in Bandung court of religion toward pandemic than before pandemic. In that matter, judge's duty as examiner and determine for suppress divorce rate. The goal of this study to describe the rate of divorce in march-december 2020, learn of the judge's efforts to suppress divorce rates, and to analyze the effectiveness of the judge's efforts to divorce rates. The study uses a qualitative approach to the type of field data. Data sources collected from primary and secondary data, data obtained using interview and documentation techniques. And then analyze the data by qualitative. The result of research can be determined that the divorce caused by quarrels and argued in the Bandung court of religion was the highest reason, the PSBB had 86-134 cases/month and 277-288 cases/month at the AKB. The background of quarreled and argued is largely caused by economics or nafkah and affair. The judge's attempt to suppress the divorce rate is to reconcile and giving advise by religion and social. The effectiveness of the judge's efforts is not optimal due to the amount of causes, with limited time and teribbly domestic conditions.
\end{abstract}

Keywords: Judge's Effort, Divorce, Quarreled and Argued, COVID-19 Pandemic.

\begin{abstract}
Abstrak. Pandemi COVID-19 menyebabkan permasalahan pada kehidupan rumah tangga yang paling berdampak adalah ekonomi atau nafkah yang mengakibatkan terus menerus suami istri berselisih dan bertengkar hingga tidak dapat didamaikan lagi kemudian mengajukan perceraiannya ke Pengadilan Agama Bandung. Perceraian akibat perselisihan dan pertengkaran terus menerus menjadi alasan paling tinggi di Pengadilan Agama Bandung pada saat pandemi dibandingkan dengan sebelum pandemi. Hal tersebut mendorong hakim sebagai pemeriksa dan pemutus perkara perceraian untuk menekan tingkat perceraian akibat perselisihan dan pertengkaran tersebut. Tujuan penelitian ini untuk mendeskripsikan tingkat perceraian pada bulan Maret-Desember 2020, mengetahui upaya hakim menekan tingkat perceraian, dan menganalisi efektivitas upaya hakim terhadap tingkat perceraian. Penelitian ini menggunakan pendekatan kualitatif dengan jenis data lapangan. Sumber data dikumpulkan dari data primer dan sekunder, data diperoleh menggunakan teknik wawancara dan dokumentasi. Kemudian data dianalisis secara kualitatif. Dari hasil penelitian dapat disimpulkan perceraian akibat perselisihan dan pertengkaran di Pengadilan Agama Bandung menjadi alasan tertinggi, selama PSBB terdapat 86-134 perkara/bulan dan 277-288 perkara/bulan saat AKB. Latar belakang perselisihan dan pertengakaran banyak disebabkan oleh ekonomi atau nafkah dan perselingkuhan. Upaya hakim menekan tingkat perceraian adalah mendamaikan dan memberi nasihat agama dan nasihat sosial. Efektivitas upaya hakim tersebut belum optimal dikarenakan banyaknya perkara sedangkan waktu terbatas serta kondisi rumah tangga yang sudah parah.
\end{abstract}

Kata Kunci: Upaya Hakim, Perceraian, Perselisihan dan Pertengkaran, Pandemi COVID-19. 


\section{A. Pendahuluan}

Pada Maret 2020, pemerintah mengupayakan kebijakan untuk mencegah penyebaran COVID19 dengan Pembatasan Sosial Berskala Besar (PSBB) yakni membatasi aktivitas masyarakat di luar rumah, termasuk aktivitas di Pengadilan Agama. Pandemi menyebabkan banyaknya sektor ekonomi tidak dapat berjalan sebagaimana mestinya, sehingga suami kehilangan pekerjaannya dan tidak dapat memberi nafkah. Hal tersebut mengakibatkan permasalahan di rumah tangga, suami istri terus menerus berselisih dan bertengkar. Hingga ada yang tidak dapat didamaikan lagi dan memutuskan untuk bercerai.

Perceraian secara hukum berarti putusnya perkawinan, yang mengakibatkan putusnya hubungan sebagai suami istri atau berhenti menjadi bersuami-istri. Perkawinan dapat putus karena kematian, perceraian, dan atas keputusan Pengadilan sebagaimana dalam Pasal 38 Undang-Undang No. 1 Tahun 1974 tentang Perkawinan (selanjutnya disingkat UU No. 1 Tahun 1974).

Perceraian hanya dapat dilakukan di depan sidang Pengadilan setelah Pengadilan yang bersangkutan berusaha dan tidak berhasil mendamaikan kedua belah pihak sebagaimana dalam Pasal 65 Undang-Undang No. 7 Tahun 1989 tentang Peradilan Agama (selanjutnya disingkat UU No. 7 Tahun 1989).

Mengajukan perceraian harus ada cukup alasan, bahwa suami istri itu tidak akan dapat hidup rukun sebagai suami istri sebagaimana dalam Pasal 39 ayat (2) UU No. 1 Tahun 1974. Perceraian dapat terjadi karena alasan atau alasan-alasan sebagaimana dalam Pasal 19 Peraturan Pemerintah No. 9 Tahun 1975 tentang Pelaksanaan Undang-Undang No. 1 Tahun 1974 tentang Perkawinan (selanjutnya disingkat PP No.9 Tahun 1975), yaitu:

1. Salah satu pihak berbuat zina atau menjadi pemabuk, pemadat, penjudi dan lain sebagainya yang sukar disembuhkan;

2. Salah satu pihak meninggalkan pihak lain selama 2 (dua) tahun berturut-turut tanpa izin pihak lain dan tanpa alasan yang sah atau karena hal lain diluar kemampuannya;

3. Salah satu pihak mendapat hukuman penjara 5 (lima) tahun atau hukuman yang lebih berat setelah perkawinan berlangsung;

4. Salah satu pihak melakukan kekejaman atau penganiayaan berat yang membahayakan pihak lain;

5. Salah satu pihak mendapat cacat badan atau penyakit dengan akibat tidak dapat menjalankan kewajibannya sebagai suami atau isteri;

6. Antara suami dan isteri terus menerus terjadi perselisihan dan pertengkaran dan tidak ada harapan akan hidup rukun lagi dalam rumah tangga.

Selanjutnya alasan perceraian tersebut dilengkapi dengan dua alasan perceraian sebagaimana dalam Pasal 116 Kompilasi Hukum Islam (selanjutnya disingkat KHI), yaitu alasan suami melanggar taklik talak dan alasan peralihan agama atau murtad yang menyebabkan terjadinya ketidakrukunan dalam rumah tangga.

Kemudian pada Juni 2020, barulah Pemerintah Provinsi Jawa Barat mengeluarkan kebijakan Adaptasi Kebiasaan Baru (AKB) yang diharapkan dapat memulihkan kesejahteraan masyarakat dan menyadarkan masyarakat untuk beraktivitas di luar rumah dengan mematuhi protokol kesehatan. Kegiatan pelayanan di Pengadilan Agama Bandung pun mulai normal kembali, hal tersebut mengakibatkan gugatan atau permohonan cerai ke Pengadilan Agama Bandung menumpuk. Sehingga berpengaruh terhadap tingkat perceraian yang dapat dilihat dalam tabel berikut:

Tabel 1. Statistik Alasan Perceraian di Pengadilan Agama Bandung Tahun 2018-2020

\begin{tabular}{|c|l|c|c|c|}
\hline No & \multicolumn{1}{|c|}{ Alasan Perceraian } & $\begin{array}{c}\text { Tahun } \\
\mathbf{2 0 1 8}\end{array}$ & $\begin{array}{c}\text { Tahun } \\
\mathbf{2 0 1 9}\end{array}$ & $\begin{array}{c}\text { Tahun } \\
\mathbf{2 0 2 0}\end{array}$ \\
\hline 1 & Ekonomi & 2295 & 2909 & 2275 \\
\hline
\end{tabular}




\begin{tabular}{|c|l|c|c|c|}
\hline $\mathbf{2}$ & $\begin{array}{l}\text { Perselisihan dan } \\
\text { pertengkaran terus menerus }\end{array}$ & $\mathbf{1 6 4 0}$ & $\mathbf{2 0 2 5}$ & $\mathbf{2 5 0 9}$ \\
\hline 3 & Meninggalkan salah satu pihak & 374 & 470 & 391 \\
\hline 4 & Kekerasan dalam rumah tangga & 92 & 89 & 51 \\
\hline 5 & Mabuk & 46 & 31 & 21 \\
\hline 6 & Poligami & 21 & 22 & 8 \\
\hline 7 & Murtad & 19 & 24 & 28 \\
\hline 8 & Judi & 4 & 13 & 12 \\
\hline 9 & Dihukum penjara & 2 & 4 & 6 \\
\hline 10 & Madat & 2 & 3 & 3 \\
\hline 11 & Cacat badan & 1 & 2 & 2 \\
\hline 12 & Kawin paksa & 4.510 & 5.611 & 5.319 \\
\hline 13 & Zina & & & 12 \\
\hline & & & 13 & 12 \\
\hline
\end{tabular}

Sumber: http://pa-bandung.go.id/layanan-publik/statistik-pengadilan.

Berdasarkan latar belakang masalah maka peneliti merumuskan masalah sebagai berikut: "Bagaimana tingkat perceraian akibat perselisihan dan pertengkaran terus menerus pada masa pandemi COVID-19 selama Maret-Desember 2020 di Pengadilan Agama Bandung?", "Bagaimana upaya hakim menangani perceraian akibat perselisihan dan pertengkaran terus menerus pada masa pandemi COVID-19 di Pengadilan Agama Bandung?" dan "Bagaimana efektivitas upaya hakim terhadap tingkat perceraian akibat perselisihan dan pertengkaran terus menerus pada masa pandemi COVID-19 di Pengadilan Agama Bandung?"

Adapun tujuan dari penelitian adalah sebagai berikut:

1. Untuk mendeskripsikan tingkat perceraian akibat perselisihan dan pertengkaran terus menerus pada masa pandemi COVID-19 selama Maret-Desember 2020 di Pengadilan Agama Bandung.

2. Untuk mengetahui upaya hakim menangani perceraian akibat perselisihan dan pertengkaran terus menerus pada masa pandemi COVID-19 di Pengadilan Agama Bandung.

3. Untuk menganalisis efektivitas upaya hakim terhadap tingkat perceraian akibat perselisihan dan pertengkaran terus menerus pada masa pandemi COVID-19 di Pengadilan Agama Bandung.

\section{B. Metodologi Penelitian}

Penelitian ini menggunakan pendekatan kualitatif yakni mendeskripsikan fenomena perceraian akibat perselisihan dan pertengkaran pada masa pandemi COVID-19 di Pengadilan Agama Bandung. Sedangkan jenis data diperoleh peneliti dengan secara langsung terjun ke lapangan (field data). Sumber data dikumpulkan dari data primer dan sekunder, data diperoleh menggunakan teknik wawancara dan dokumentasi.

Wawancara yang dimaksud adalah tanya jawab satu arah dengan Hakim di Pengadilan Agama Bandung sebagai informan yang mengetahui kondisi latarbelakang perceraian dan upaya JRHKI is licensed under Creative Commons Attribution- 
hakim untuk mendapatkan informasi yang sesuai dengan rumusan masalah. Dokumentasi yang dimaksud adalah pengambilan data laporan statistik perkara perceraian bulanan, data statistik perkara perceraian tahunan dan putusan perkara perceraian. Kemudian data dianalisis secara kualitatif.

\section{Hasil Penelitian dan Pembahasan}

Tingkat Perceraian Akibat Perselisihan dan Pertengkaran Terus Menerus pada Masa Pandemi COVID-19 Selama Maret-Desember 2020 di Pengadilan Agama Bandung

Tingkat perceraian dengan faktor yang paling dominan mengalami perubahan yang signifikan dibulan tertentu karena adanya pembatasaan pelayanan di Pengadilan Agama Bandung selama PSBB berlangsung di bulan Maret. Hingga bulan Juni diberlakukan adaptasi kebiasaan baru yang mengembalikan pelayanan di Pengadilan Agama Bandung. Perubahan tersebut dipaparkan dalam grafik batang berikut:

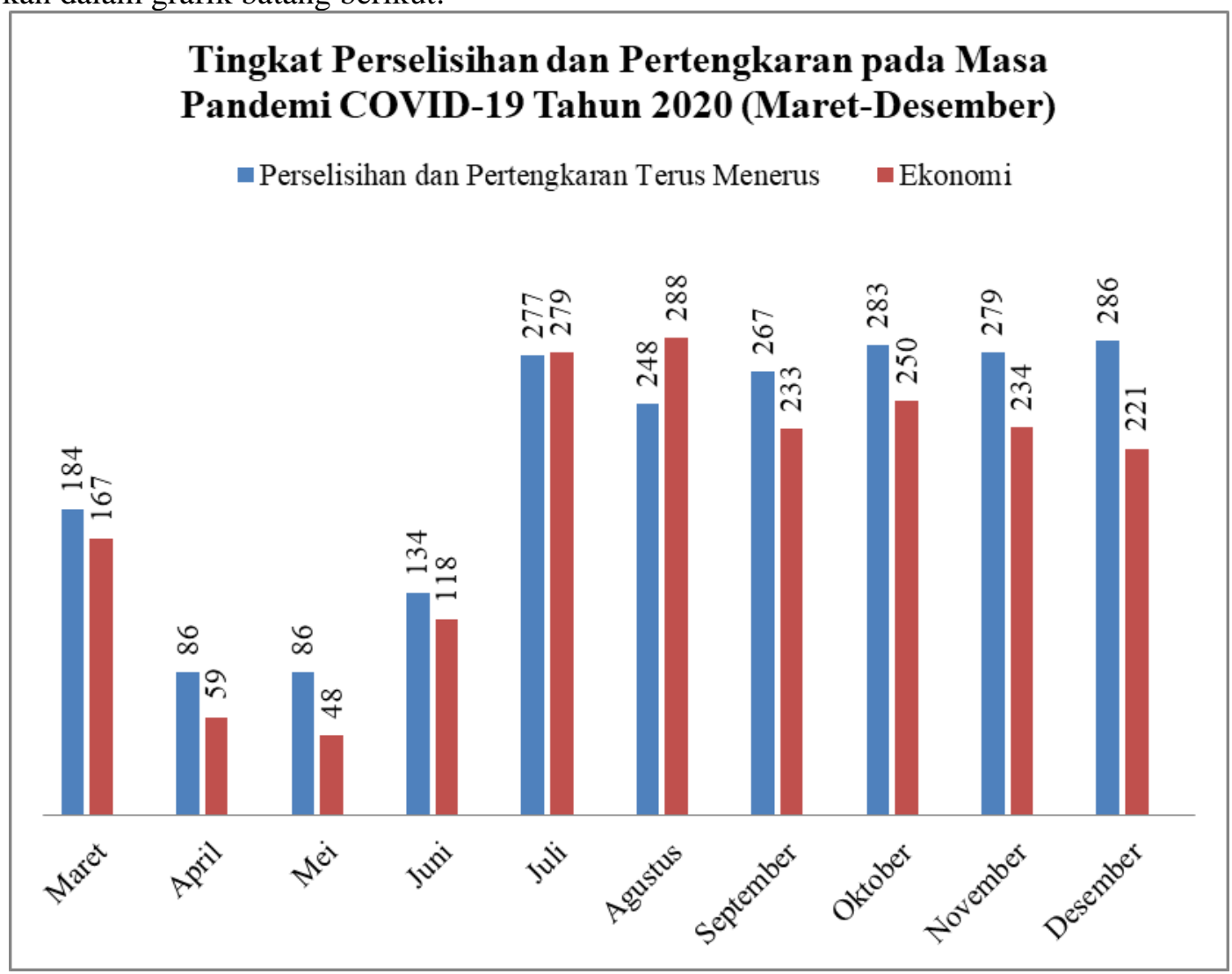

Sumber: Laporan Faktor-Faktor Penyebab Terjadinya Perceraian Pada Pengadilan Agama Bandung

Gambar 1. Grafik Tingkat Perselisihan dan Pertengkaran pada Masa Pandemi COVID-19 Tahun 2020 (Maret-Desember)

Pada bulan Maret diumumkannya PSBB angka faktor perselisihan dan pertengkaran terus menerus berada di 184 perkara dan faktor ekonomi berada di 167 perkara. Pada bulan April-Mei kedua faktor tersebut menurun setengah lebih kecil dari bulan sebelumnya. Pada bulan Juni awal diberlakukannya AKB, mulai ada peningkat kembali seperempat dari bulan sebelumnya. Selanjutnya di bulan Juli-Desember faktor perselisihan dan pertengkaran terus menerus berada di antara 277-286 perkara perbulannya dan faktor ekonomi berada di antara 221-288 perkara perbulannya.

Selama masa pandemi COVID-19 penggugat/pemohon mengajukan gugatan atau permohonan cerai lebih tinggi karena rumah tangga yang tidak dapat rukun lagi karena terus menerus terjadi perselisihan dan pertengkaran. Salah satu hakim Pengadilan Agama Bandung mengungkapkan bahwa latar belakang atau sebab terjadinya perselisihan dan pertengkaran 
suami istri dipicu oleh persoalan ekonomi dan perselingkuhan. Pendapat hakim dikuatkan dengan beberapa putusan yang peneliti peroleh.

Ekonomi yang terhimpit disebabkan karena suami terkena PHK dari pekerjaannya di masa pandemi. Sehingga tidak mampu menafkahi istri dan memenuhi kehidupan rumah tangga mereka dan istri menggugat karena hal tersebut. Adapun suami yang masih memiliki pekerjaan namun penghasilan sedikit mentalak istri karena istri kurang menerima nafkah yang diberikan namun angka cerai talak lebih sedikit dibanding cerai gugat.

Perselingkuhan tidak sedikit terjadi di masa pandemi, istri yang mengetahui suami telah memiliki Wanita Idaman Lain (WIL) atau suami mengetahui istri memiliki Pria Idaman Lain (PIL) dari bukti berupa chatting-an mesra atau foto berduaan maupun pengakuan langsung dari pihak yang berselingkuh. Bahkan menurut pengakuan suami atau istri yang diselingkuhi, diamdiam pasangannya telah menikah dengan selingkuhannya.

Selain kedua sebab tersebut ada sebab-sebab lainnya seperti istri nusyuz/ tidak mau taat pada suami (cerai talak) dan hal lainnya seperti berselisih pendapat dalam membina rumah tangga, krisis akhlak atau buruk perangai dan adanya campur tangan pihak keluarga. Adapun dalam satu kasus sekaligus terdapat beberapa sebab seperti suami yang tidak menafkahi istri dan main hati dengan wanita lain atau istri yang tidak mau taat pada suami dan pergi begitu saja dengan pria lain.

Setelah terjadi perselisihan dan pertengkaran terus menerus pihak keluarga berupaya mendamaikan kedua pihak, namun tidak banyak yang berhasil. Kebanyakan sudah tidak berkomunikasi dengan baik dan memilih pisah ranjang atau pisah rumah, bahkan ada yang sudah tidak diketahui keberadaanya. Karena dilihat rumah tangga tidak dapat dipertahankan istri atau suami memilih untuk mengajukan gugatan atau permohonan cerai ke Pengadilan.

\section{Upaya Hakim Menangani Perceraian Akibat Perselisihan dan Pertengkaran Terus Menerus pada Masa Pandemi COVID-19 di Pengadilan Agama Bandung}

Meskipun upaya perdamaian sudah dilakukan oleh mediator pada saat mediasi, tetapi selama perkara perceraian belum diputuskan, hakim yang memeriksa dapat berusaha mendamaikan kedua pihak pada setiap sidang ini dijelaskan dalam Pasal 31 PP No. 9 Tahun 1975 Jo Pasal 82 UU No. 7 Tahun 1989. Upaya perdamaian yang dibarengi dengan pemberian nasihat dalam perkara perceraian lebih sering dan intens dengan maksud membuka peluang kedua pihak untuk saling bertoleransi dan mencapai titik temu sehingga perceraian dapat dihindari. Inilah Fungsi hakim dalam menekan tingkat perceraian hanya sebatas mendamaikan dan memberi nasihat dalam sidang. Standar nasihat-nasihat yang biasa hakim sampaikan ada 2 (dua) yaitu:

1. Nasihat agama, karena pada dasarnya pernikahan merupakan ibadah. Nasihat dengan nilai-nilai agama disesuaikan dengan penyebab terjadinya perselisihan dan pertengkaran. Misalnya nasihat agama dalam masalah ekonomi atau nafkah seperti rezeki itu ditangan Allah sudah ada takarannya. Jika karena perselingkuhan memberi nasihat bahwa memaafkan itu lebih baik dan jika seseorang bertaubat memperbaiki diri alangkah baiknya kalau diterima kembali oleh pihak yang menggugat.

2. Nasihat sosial, termasuk berhubungan dengan anak. Misalnya terhadap psikis anak bagaimana jika nanti akan menikah dalam kondisi orang tua bercerai maka bisa mengalami trauma dan kebahagiaannya akan berkurang.

Hakim menegaskan bahwa sebenarnya yang paling mendasar itu akhlak seseorang baik suami maupun istri. Jika mereka memiliki akhlak yang artinya mendalami nilai-nilai Islam, maka masalah apapun dapat dilalui. Misalnya masalah nafkah kurang dan keduanya tidak saling menyalahkan, saling introspeksi dan menyadari dengan keimanannya bahwa rezeki itu sudah diatur oleh Allah, maka tidak mungkin adanya pertengkaran. Tetapi dikarenakan salah satu atau keduanya nilai-nilai agamanya tidak diterapkan sehingga timbullah emosi masing-masing. Alasan perselingkuhan terjadi karena dia pun melepaskan nilai-nilai agamanya, sehingga akhlaknya tidak terpuji.

Jadi segala sesuatu itu bersumber pada penerapan nilai-nilai agama. Sehebat apapun masalah jika mereka masih berpegang teguh pada nilai agama, maka Allah menjamin jalan keluarnya dan tidak perlu ada perceraian. Terjadinya pertengkaran antara suami istri karena 
masing-masing berekspetasi yang terlalu tinggi kemudian tidak mendapatkan sehingga kekecewaan yang malah didapat. Jika masing-masing dapat saling memaham, mungkin masalah perceraian dapat ditekan.

\section{Efektivitas Upaya Hakim terhadap Tingkat Perceraian Akibat Perselisihan dan Pertengkaran Terus Menerus pada Masa Pandemi COVID-19 di Pengadilan Agama Bandung}

Peniadaan pelayanan dan persidangan selama PSBB di bulan Maret-Mei tahun 2020 dan hingga bulan Juni tahun 2020 pelayanan dan persidangan kembali dibuka di Pengadilan Agama Bandung, menyebabkan membludaknya perkara yang masuk dan banyaknya sidang yang tertunda. Sehingga mempengaruhi upaya hakim dalam mendamaikan dan menasihati kedua pihak yang terkendala oleh waktu dan banyaknya perkara. Sehingga upaya hakim menekan tingkat perceraian kurang efektif.

Menurut hakim perceraian yang diajukan hampir 90\% dikatakan dikabulkan oleh majelis hakim dikarenakan para pihak yang sudah berkeyakinan untuk tetap bercerai dan karena perkara di Bandung itu banyak waktu yang diberikan tidak mencukupi, sehingga tingkat keberhasilan hakim mengusahakan perdamaian dan memberi nasihat itu sangat minim. Disebabkan pula ketidakhadiran tergugat atau termohon untuk menggunakan haknya untuk membantah dalil gugatan atau permohonan dan dipandang membenarkan dalil tersebut, sehingga perkara diperiksa dan diputus dengan verstek.

Berdasarkan hasil wawancara yang peneliti lakukan, terdapat faktor penghambat tercapainya efektivitas dalam menekan tingkat perceraian di Pengadilan Agama Bandung. Diantaranya adalah sebagai berikut:

1. Kondisi Pengadilan, karena banyaknya perkara perceraian di Bandung berimbas pada upaya perdamaian dan pemberian nasihat kepada kedua pihak. Upaya mendamaian dan memberi nasihat pada prakteknya di Pengadilan terkendala oleh banyaknya perkara sehingga waktu untuk menasihati para pihak tidak cukup hanya 10 menit saja. Sebagaimana pendapat asmu'i syarkowi para hakim Pengadilan Agama dihadapkan kepada dua hal yang sama-sama dilematis, yaitu antara mengedapankan hati nurani (kualitas) dalam memeriksa perkara perceraian atau bekerja memenuhi target angka tinggi (kuantitatif) penyelesaian perkara.(Syarkowi, 2021)

2. Kondisi rumah tangga, dikarenakan kebanyakan posisi mereka ketika mengajukan perceraian dalam kondisi sudah bercerai secara di luar pengadilan, bahkan ada yang sudah talak tiga. Sehingga ke Pengadilan hanya untuk melegalkan saja. Jadi hakim sulit mendamaikan dan memberi nasihat karena mereka sudah membentengi diri bahwa mereka berkeyakinan untuk bercerai. Namun ada pun rumah tangga yang baru bermasalah relatif lebih mudah untuk didamaikan dan diberi nasihat.

Jadi sebelum mengajukan perceraian ke Pengadilan banyak pasangan yang sudah berlarut-larut dalam perselisihan dan pertengkaran yang sudah parah, dikarenakan sudah tidak ada ikatan cinta antara suami dan istri dalam penyelesaian masalah rumah tangga mereka. Sehingga rumah tangga dianggap tidak dapat dipertahankan dan sudah tidak ada manfaatnya lagi. Akhirnya memutuskan untuk mengakhiri ikatan perkawinan secara resmi lewat Pengadilan Agama.

Sebagaimana Putusan Mahkamah Konstitusi Nomor 38/PUU-IX/2011 bahwa ketika terjadi perselisihan dan pertengkaran yang terus menerus di antara pasangan suami istri, sehingga sulit diharapkan untuk bersatu kembali. Dalam keadaan seperti itu, maka ikatan batin dalam perkawinan dianggap telah pecah (broken marriage), meskipun ikatan lahir secara hukum masih ada. Dalam keadaan yang demikian, hukum harus memberikan jalan keluar, jalan keluar itulah pembubaran perkawinan yang di dalam Pasal 38 UU No.1 Tahun 1974 disebut dengan putusnya perkawinan dengan perceraian atau dengan putusan pengadilan.

Hakim mempertimbangkan hukumnya bukan dari melihat siapa yang salah dan siapa yang benar, namun menganalisa gugatan atau permohonan, jawab-menjawab mana yang diakui dan tidak diakui, mana yang mampu membuktikan dan tidak mampu membuktikan. Sehingga hakim menemukan fakta di persidangan bahwa perselisihan dan pertengkaran terus menerus 
terbukti dan perkawinan tidak dapat dipertahankan lagi. Jika dipertahankan, maka akan kemungkinan terjadi keburukan yang lebih besar ketimbang manfaatnya.

Gugatan atau permohonan perceraian yang diajukan ke Pengadilan Agama hanya untuk memutus ikatan lahir saja dengan kata lain memutus tali perkawinan secara legal. Karena pada dasarnya ikatan batin antara penggugat atau pemohon dengan tergugat atau termohon sudah pecah (broken marriage).

Jika keluarga sudah merukunkan dan mediator sudah mengupayakan perdamaian namun tidak berhasil, maka hakim adalah pintu terakhir nasihat yang dapat mencegah perceraian yang merupakan jalan putusnya nasihat. Dengan sifat bijaksanaannya hakim dapat mendamaikan dan menasihati dengan kata-kata yang menyentuh hati dan kata-kata yang memiliki kekuatan ada pada optimisme hakim. Hakim berupaya pula memeriksa perkara dengan teliti dan rasional apakah sebab-sebab perselisihan dan pertengkaran yang terdapat dalam dalil gugatan atau permohonan perceraian terbukti dan apakah memiliki pengaruh yang prinsipil.

Menurut penulis nasihat-nasihat dalam mengingat kepada agama dan dampak sosial perceraian terhadap anak tepat hanya saja ada yang kurang. Karena ada hambatan yakni para pihak yang sudah membentengi diri, jadi nasihat-nasihat kurang masuk ke hati. Para pihak sebaiknya diajak untuk merenung, seperti yang diterapkan dalam terapi psikologis islam, langkahnya:

1. Diajak memahami realita apa yang sebenarnya yang sedang dihadapi, misalnya seorang istri dibuat kecewa oleh suami atau suami tidak dihargai oleh istri. Harus disadari bahwa istri sudah mempertimbangkan dan memutuskan untuk menikahi suaminya adalah pilihan dan apa-apa yang baru diketahui setelah menikah tentang kekurangan suami adalah takdir yang harus diterima, dan begitu pun suami sebaliknya.

2. Diajak kembali memahami mengenali siapa dirinya, sepasang suami istri juga seorang ayah dan ibu yang kedua-duanya sangat dibutuhkan oleh anak-anaknya, yang tidak dapat tergantikan posisinya. Sebenarnya istri sangat dicintai dan dibutuhkan suami dan begitupun sebaliknya, hanya saja sulit untuk mengekspresikannya.

3. Diajak untuk memahami keadaan yang sedang berlangsung di sekitarnya, bahwa keadaan memang sedang berubah, misalnya adanya musibah COVID-19 dengan begitu banyak permasalahan rumah tangga, dari masalah buruknya komunikasi hingga terhimpit ekonomi. Musibah adalah sunatullah yang tidak bisa ditolak dan yang terpenting adalah bagaimana mensikapi dan mengantisipasi perubahan itu.

4. Terakhir diajak untuk meyakini bahwa Allah Maha Adil yang tidak akan membebani seseorang dengan beban yang tidak dapat dipikulnya. Diajak juga untuk meyakini bahwa dengki, malas dan putus asa adalah tercela dan tidak berguna. Bahwa berbuat baik pada pasangan walaupun tidak dianggap itu lebih baik di mata Allah daripada tidak berbuat kebaikan karena mengharap balasan.

Pendapat penulis dijelaskan juga oleh Muhammad Misbahul Huda Anjaya dalam skripsinya, bahwa kemampuan Hakim dalam hal penasehatan, konsultasi dan konseling merupakan salah satu faktor yang menjadi pendukung dalam mengupayakan terjadinya perdamaian.(Anjaya, 2007) Kemudian hakim pun harus memiliki komunikasi interpersonal yang baik sehingga dapat menggunakan bahasa yang cermat disaat yang tepat serta keikhlasan dan rasa empati yang sempurna kepada para pihak yang bersengketa sebagaimana menurut Yanis Saputra(Saputra, 2021).

Dengan demikian, hakim harus memiliki keyakinan bahwa setiap perkara perceraian yang datang kepadanya pasti ada celah untuk dapat diperbaiki rumah tangganya. Perselisihan yang terjadinya dapat dihadapi secara sehat oleh suami istri tersebut dan pertengkaran dapat dihindari, sehingga suami istri tidak hanya mampu bertahan saja namun mampu berkembang kedewasaannya menghadapi masalah apapun. Jangan sampai hakim dengan pesimis beranggapan bahwa perkara perceraian yang datang kepadanya pasti sudah pecah rumah tangganya atau broken marriage. Sehingga tingkat perceraian mampu ditekan walaupun dengan waktu yang terbatas secara optimal dan optimis oleh hakim.

\section{Kesimpulan}

JRHKI is licensed under Creative Commons Attribution- 
Berdasarkan penelitian yang telah dilaksanakan oleh penulis, maka kesimpulan yang dapat diambil dari skripsi ini adalah sebagai berikut:

1. Angka Perceraian akibat perselisihan dan pertengkaran terus menerus mengalami peningkatan dan menjadi alasan paling tinggi pada masa COVID-19 di Pengadilan Agama Bandung. Latar belakang terjadinya perselisihan dan pertengakaran banyak disebabkan oleh faktor ekonomi atau nafkah dan perselingkuhan.

2. Upaya hakim menekan tingkat perceraian ditekankan pada mendamaikan dan memberi nasihat kepada para pihak. Hakim memberi nasihat-nasihat seperti nasihat agama tergantung pada sebab perselisihan dan pertengkaran serta nasihat dampak sosialnya bagi anak.

3. Tingkat keberhasilan hakim dalam menekan tingkat perceraian sangat mini dikarena terhambat oleh faktor banyaknya perkara yang masuk sehingga waktu tidak mencukupi dan faktor kondisi rumah tangga yang sudah putus ikatan batinnya sehingga ke Pengadilan Agama untuk memutus ikatan lahirnya saja.

\section{Acknowledge}

Terima kasih kepada Pengadilan Agama Bandung atas ketersediaannya untuk membantu memperoleh data-data dalam kebutuhan penelitian ini.

\section{Daftar Pustaka}

[1] Anjaya, Muhammad Misbahul Huda. Upaya Hakim Dalam Mendamaikan Perkara Perceraian Di Pengadilan Agama Banyumas Tahun 2002-2004. Universitas Islam Negeri Sunan Kalijaga Yogyakarta; 2007.

[2] Mahkamah Konstitusi. Putusan Nomor 38/PUU-IX/2011; 2011.

[3] Redaksi Sinar Grafika. Amandemen Undang-Undang Peradilan Agama (UU RI Np. 50 Th. 2009). Jakarta: Sinar Grafika; 2015.

[4] Republik Indonesia. Peraturan Pemerintah Nomor 9 Tahun 1975 Tentang Pelaksanaan Undang-Undang Nomor 1 Tahun 1974 Tentang Perkawinan. Jakarta: Sekretariat Negara; 1975.

[5] Saputra Y. Peran Aktif Hakim dalam Upaya Perdamaian Terhadap Perkara Perceraian di Pengadilan Agama Maninjau (Perkara No. 80/Pdt.G/2021/PA.Min) [Internet]. Pengadilan Agama Maninjau; 2021. Available from: https://www.pamaninjau.go.id/berita/artikel/503-peran-aktif-hakim-dalam-upaya-perdamaianterhadap-perkara-perceraian-di-pengadilan-agama-maninjau

[6] Syarkowi A. Perceraian dan Kepiluan Hati Hakim [Internet]. Badan Peradilan Agama Mahkamah Agung; 2021. Available from: https://badilag.mahkamahagung.go.id/artikel/publikasi/artikel/perceraian-dankepiluan-hati-hakim-oleh-h-asmu-i-syarkowi-2-9

[7] Tim Redaksi Nuansa Aulia. Kompilasi Hukum Islam. Bandung: CV. NUANSA AULIA; 2017.

[8] Undang-Undang Nomor 1 Tahun 1974 Tentang Perkawinan, in Kompilasi Hukum Islam. Bandung: CV. NUANSA AULIA; 2017.

[9] Dariah, Atin, interview by Mujaadilah (Bandung: Kantor Pengadilan Agama Bandung, 24 Desember 2021)

[10] Mustopa, interview by Mujaadilah (Bandung: Kantor Pengadilan Agama Bandung, 1 Desember 2021). 